\title{
'Les anglicismes polluent la langue française'. Purist attitudes in France and Quebec
}

\author{
OLIVIA WALSH \\ University of Cambridge
}

(Received November 20I2; revised June 20I3; first published online 30 July 20I3)

\section{A B S T RAC T}

It is often claimed that France is a particularly purist country; the Académie française is seen to be representative of a purist outlook and popular works such as Étiemble's attack on English influence Parlez vous franglais? (Étiemble, I964) have served to bolster this view. However, this claim has not been empirically verified. In order to determine whether or not the rhetoric around purism in France matches the reality, we developed a questionnaire to investigate whether or not ordinary speakers of French in France are purist, taking the theoretical framework in George Thomas's Linguistic Purism as a base (Thomas, I99I). This questionnaire was distributed online to a random sample of participants in France. To contextualise the findings, the questionnaire was also distributed to French speakers in Quebec. The results of the study show that, contrary to expectations, the French respondents display only mild purism and the Québécois respondents are more purist in the face of English borrowings (external purism). However, the French respondents are more concerned with the structure or 'quality' of the French language itself (internal purism) than their Québécois counterparts. This study also highlights some problems with Thomas's framework, which requires some modification for future research.

\section{INTRODUCTION}

France has long been associated with linguistic purism. So widespread is this association that, to cite Paveau and Rosier, 'il est classique de faire de l'attitude puriste un trait typiquement français' (Paveau and Rosier, 2008: 37). Although this idea is widely held, it has not been empirically verified in any systematic way. Are French speakers in France really purist? On the one hand, the existence of the Académie française, the long history of linguistic laws and the existence of numerous bodies that attempt to implement these laws would appear to suggest that they are. These all relate to language usage at the official level. However, language at the non-official level, that is, the language use and attitudes of individual members of the speech community, is just as important if we are to understand linguistic purism in contemporary France. Are 'ordinary' speakers of French also purist? Does the 


\section{Olivia Walsh}

language ideology that exists in France at the official level affect their linguistic consciousness? We may expect them to hold more purist attitudes towards their language than speakers in a country less associated with a strongly purist rhetoric, but is this actually the case? This article aims to determine whether or not the rhetoric around purism in France matches the reality, specifically at the level of individual speakers of French. An investigation of linguistic purism at this level has allowed us to test the hypothesis that speakers of French in France are very purist. A comparative investigation of linguistic purism amongst individual speakers in Quebec is also presented. If France really is the typical purist country, then we would expect French speakers in France to be more purist than those in Quebec, hence the additional (related) hypothesis: French speakers in France are more purist than French speakers in Quebec. These hypotheses are tested using the theoretical framework developed in George Thomas's Linguistic Purism (I99I), which provides 'the first broadly comparative and cross-cultural study of purism' (Thomas, I99I: 2). Testing the hypotheses serves a dual purpose: it provides a comparative profile of purism at the individual level in France and Quebec but also allows Thomas's framework to be assessed for completeness and robustness and to be modified or expanded where necessary. ${ }^{1}$

Thomas's framework was used to design a questionnaire to measure purist attitudes and behaviour in France. The questionnaire measures both external purism, aimed at foreign elements, and internal purism, aimed at the structure or 'quality' of the French language itself. There exists in both France and Quebec terminology commissions, official bodies established to create replacement French terms for anglicisms that have been borrowed into the language. In order to measure levels of external purism, we included in the questionnaire a sample of anglicisms targeted by these bodies, along with their French replacements (for example, the commonly used 'email' and its replacement courriel). This allowed us to determine respondents' attitudes towards anglicisms, and their levels of knowledge and acceptance of replacements, which provides an indication of the impact these official purist interventions have had. Attitudes towards internal purism, specifically, elitist purism, which is negative towards any non-standard speech, were examined by measuring reactions to usages which are contrary to prescribed norms.

\section{THOMAS'S FRAMEWORK}

Thomas bases his framework on a broad definition of linguistic purism, described as:

the manifestation of a desire on the part of the speech community (or some section of it) to preserve a language from, or rid it of, putative foreign elements held to be undesirable (including those originating in dialects, sociolects and styles of the same language). It may be directed at all linguistic levels, but primarily the lexicon. Above

${ }^{1}$ Providing this critical analysis of Thomas's framework is necessary, because the current study is the first that uses his framework in any detail to examine an instance of purism. 
all, it is an aspect of the codification, cultivation and planning of standard languages (Thomas, I99I: 2).

Purism thus includes ideas which are also common to standardisation and prescriptivism, for example, the notion that some elements of language are desirable while others are not. However, purism goes further by introducing the following ideas: only one form of the language is the correct (or even the 'perfect') form (generally this form is the standard form); this language is currently pure and, therefore, change to it equals contamination or corruption of some sort; the language must be protected from this contamination and preserved in its current state (or, alternatively, if the language has already begun to be corrupted, the corrupted part must be removed). Standardisation and prescriptivism do not necessarily share the themes of contamination, corruption, protection and preservation; indeed, standardisation (particularly during the elaboration stage) requires change and innovation, and codification, while laying out rules for usage, is not necessarily prescriptive. Prescriptivism, although it shares some traits with purism, in particular the idea that there is only one 'correct' form of the language, is not inherently conservative; prescriptive norms can change.

Thomas's framework is in the form of a checklist of characteristics, presented in a questionnaire, by means of which he claims we can complete a profile of purism in a given country (Thomas, I99I: I9I-I93). We have reproduced a simplified version of this checklist in Figure I, representing only those parts of the framework that are relevant to the discussion.

Questions one to eight concern the orientation of the purism. Thomas makes a general distinction between 'external' purism and 'internal' purism. The former, labelled 'xenophobic purism', involves 'removing or replacing foreign elements, whether their source is specified (targeted xenophobia) or unspecified (general xenophobia)' (Thomas, I99I: 80-8I). The latter includes archaising and reformist purism, which have a temporal basis, and ethnographic and elitist purism, which have a social basis. Archaising purism typically involves 'an attempt to resuscitate the linguistic material of a past golden age, an exaggerated respect for past literary models, and excessive conservatism towards innovations' (Thomas, I99I: 79), whereas reformist purism makes 'a conscious effort to reform, regenerate, renew or resuscitate a language' and is important in the creation of standard languages (ibid.). Ethnographic purism favours rural dialects as a source of new words, as these are seen as being in some way purer than the standard language (Thomas, I99I: 77). Elitist purism, on the other hand, is negative towards these rural dialects or any non-standard speech, and is based on the belief that language can be perfected (Thomas, I99I: 78-79). As benchmarks for measuring the puristic profile of a situation, Thomas uses the terms mild, moderate and extreme. With regard to the orientation of the purism, Thomas states that extreme purism is characterised by a combination of xenophobic purism with two internal orientations, one temporal and one social (xenophobic / reformist / ethnographic, xenophobic / reformist / elitist, xenophobic / archaising / ethnographic, xenophobic / archaising / elitist), 


\section{Olivia Walsh}

1. Is the puristic orientation external or internal?

External Internal Both

2. If both, which orientation is the dominant one?

3. If the threat is wholly or partially external, which of the following describe the threat more clearly?

Non-specific Specific

4. If specific, is more than one language involved?

Yes

No

5. If 'No', which of the following describes the language most closely?

From the same diasystem $\quad$ Related Unrelated

6. Which of the following best describes the position of the threatening languages vis-àvis the language where the purism is located?

In the same state In another state

7. Has the threatening language ever served as a language of culture for the speakers of the language where purism is involved?

Yes $\quad$ No

8. If the threat is internal, which planes and which poles are involved?

elitist ethnographic : archaising reformist

9. Which of the modes of the implementational cycle have been completed in the purism under review?

$\begin{array}{lll}\text { Censorship } & \text { Eradication } & \text { Prevention } \\ \text { Replacement } & \text { Reception } & \text { Evaluation }\end{array}$

10. Is the purism primarily or exclusively directed at the lexical level?

Yes $\quad$ No

11. If 'Yes' and the lexical purism is xenophobic, into which of the categories given in Figure 10 (1991: 172) do the targets fall?

Mild $\quad$ Moderate Extreme

12. Similarly, into which of the categories given in Figure 11 do the preferred replacements fall?
Mild
Moderate
Extreme

Figure I. Simplified checklist of characteristics for a single instance of purism (Thomas, 1991: 191-192) 
moderate purism by a combination of xenophobic purism with one of the internal orientations (xenophobic / archaising, xenophobic / reformist, xenophobic / elitist or xenophobic / ethnographic), and mild purism by 'a rough balance among the puristic orientations' (Thomas, I99I: I7I). It is unclear what exactly Thomas means by 'a rough balance' and we have therefore modified his model very slightly; given that extreme purism is characterised by a three-dimensional orientation and moderate by a two-dimensional one, it would appear logical to conclude that mild purism is characterised by a one-dimensional orientation, displaying either xenophobic purism or one of the internal perspectives.

Question nine relates to the purification cycle outlined by Thomas. The first two stages of the cycle - recognition of need, where purists decide that the language is in need of purification, and identification of targets, where they choose the categories of words to be targeted as unsuitable or undesirable - are essential for the later stages, outlined in question nine, to take place (Thomas, I991: 84-85). Thomas's definition of the censorship stage does not have the meaning we may more commonly associate with censorship (for example, it is defined by the OED as a duty 'to inspect all books, journals, dramatic pieces, etc., before publication to secure that they shall contain nothing immoral, heretical, or offensive'). Instead, it involves speakers correcting themselves or others when they notice foreign words (or words defined as unacceptable during the identification phase) being used (Thomas, I99I: 88-90). Eradication, the activity Thomas claims to be most commonly associated with purism, involves removing the unwanted elements established during the identification stage. Prevention involves protecting the language from elements which have not yet entered it. Thomas claims that this type of purism does not occur very frequently, and usually only when a language academy of some sort tries to invent appropriate terms for new objects or concepts before non-native terms for these have become widespread amongst the general public (Thomas, I99I: 9I-93). According to Thomas, replacement generally occurs simultaneously with identification and eradication and is one of the most important stages, as 'the provision of an acceptable alternative to the elements defined as undesirable is an essential component of all active purism' (Thomas, I99I: 93-94). Reception refers to the reaction of the speech community to the suggestions and replacements proposed by purists. The reaction of these speakers often determines whether or not the purist endeavour will be successful. This reaction is often dependent on how puristic suggestions are conveyed by the speech community. If they are included in dictionaries, grammars and guides to good usage, then they are more likely to be favourably viewed (Thomas, I991: 95-97). Finally, evaluation involves the appraisal of all the previous stages (or such of them as may have occurred during a particular purification attempt) either by those instigating the purism or others. This appraisal, if positive, allows the puristic intervention to be 'pronounced successful and the process is more or less complete'. If negative, however, the whole attempt at purism may either be abandoned or new targets may be identified and purism may continue with a new orientation (Thomas, I99I: 98-99). According to Thomas, mild purism does not proceed beyond the censorship phase; moderate 
purism includes replacement but does not specify the necessity of eradication and prevention and does not complete the purification cycle; extreme purism completes the cycle and ensures that the reforms are accepted by the speech community (Thomas, I99I: I7I).

Question ten refers to the linguistic level on which the purism takes place. Thomas claims that examples of purism can be found on all linguistic levels (phonological, morphological, syntactic, lexical and orthographic) (Thomas, I99I: 62-65), but makes a distinction between unmarked purism, operating at the lexical level, and marked purism, operating at the levels of smaller or larger linguistic segments; he thus views lexical purism as archetypal (Thomas, I99I: 66). Question eleven refers to the types of word which are targeted by the lexical purism. According to Thomas, mild purism is directed at loanwords from a single, nonrelated source; moderate purism is characterised by 'a rejection of all loanwords felt to be foreign', but an 'acceptance of calques and loanwords from related languages provided they can be assimilated into the morphophonemic system' and 'qualified acceptance of well-formed native neologisms'; and extreme purism involves 'a rejection of all loanwords and internationalisms' and 'scepticism or hostility towards calques', both Lehnübertragungen, that is, fairly free, partial translations, and Lehnübersetzungen, exact element-for-element translations (Thomas, I99I: I72I74). ${ }^{2}$ Question twelve concerns the replacements of these targets. Thomas claims that mild purism tolerates calques and loanwords from related languages; moderate purism tolerates calques conforming to native word-building laws, loanwords from related languages provided they can be assimilated into the morphophonemic system and well-formed neologisms; and extreme purism tolerates mainly only native neologisms, dialectalisms and archaisms but also some calques, specifically Lehnübertragungen (Thomas, I99I: I73).

A significant weakness in Thomas's model is that he does not provide definitions for the terms that he uses to categorise borrowings, nor does he provide any examples. It has been necessary, therefore, to develop our own typology of borrowings in order to measure accurately the targets and replacements of purism in France and Quebec. Much has been written on the subject of linguistic borrowing and there are numerous different typologies proposed in the literature (for example, Haugen, I950; Humbley, I974; Weinreich, I953; with relation to French specifically, Picone, I996; Walter, I997). Given that all borrowed terms included in the current study were either targeted as undesirable or suggested as replacements by the terminology commissions in France and Quebec, our intent here is not to add to the wider debate by justifying the new typology as a general classification of loanwords, but rather to propose a typology that reflects the reality of linguistic planning in France and Quebec today. Our proposed typology is therefore based upon an analysis of the official policy for choosing replacement terms in

2 Thomas bases his use of the terms Lehnübersetzung and Lehnübertragung on Werner Betz (I944) and does not provide English equivalents for these terms. They can be seen to correspond to 'loan translation' and 'loan rendition', respectively. 
Table I. Typology of borrowings

\begin{tabular}{|c|c|c|}
\hline $\begin{array}{l}\text { Type of } \\
\text { borrowing }\end{array}$ & Examples & Definition \\
\hline \multicolumn{3}{|l|}{ Loanwords } \\
\hline $\begin{array}{l}\text { Unassimilated } \\
\text { loanwords }\end{array}$ & drugstore, sandwich & $\begin{array}{l}\text { Terms borrowed from a foreign } \\
\text { language which show either no } \\
\text { assimilation, or minimal } \\
\text { phonological assimilation, to the } \\
\text { native language. }\end{array}$ \\
\hline $\begin{array}{l}\text { Assimilated } \\
\text { loanwords }\end{array}$ & $\begin{array}{l}\text { dopage 'doping', modérateur } \\
\text { 'moderator' }\end{array}$ & $\begin{array}{l}\text { Terms borrowed from a foreign } \\
\text { language, which show } \\
\text { morphological and phonological } \\
\text { assimilation to the native language. }\end{array}$ \\
\hline \multicolumn{3}{|l|}{ Calques } \\
\hline Loan translations & $\begin{array}{l}\text { photocarte 'photomap', } \\
\text { gratte-ciel 'sky-scraper' }\end{array}$ & $\begin{array}{l}\text { The exact word-for-word } \\
\text { translation of a foreign word or } \\
\text { phrase, with possible } \\
\text { morphological adaptation to the } \\
\text { native language (e.g. inversion). }\end{array}$ \\
\hline Loan renditions & $\begin{array}{l}\text { sac gonflable 'air bag', } \\
\text { position de tête 'pole } \\
\text { position' }\end{array}$ & $\begin{array}{l}\text { The part translation of a foreign } \\
\text { word or phrase, where one part is } \\
\text { exactly translated and one part is } \\
\text { created or freely translated into } \\
\text { the native language. }\end{array}$ \\
\hline Semantic loans & $\begin{array}{l}\text { réaliser 'to realise', now } \\
\text { means 'to become aware } \\
\text { of, due to English } \\
\text { influence, in addition to } \\
\text { its original meaning 'to } \\
\text { carry out [a project]' }\end{array}$ & $\begin{array}{l}\text { Native words have an additional } \\
\text { meaning added to them which has } \\
\text { been borrowed from a foreign } \\
\text { word. }\end{array}$ \\
\hline \multicolumn{3}{|l|}{ Loan creations } \\
\hline Loan creations & $\begin{array}{l}\text { jardinerie 'garden centre', } \\
\text { logiciel 'software' }\end{array}$ & $\begin{array}{l}\text { The creation of a new word to } \\
\text { express the meaning of a foreign } \\
\text { word. }\end{array}$ \\
\hline
\end{tabular}

France and Quebec. ${ }^{3}$ We outline in Table I only those types of borrowing that are relevant to the current study; namely, loanwords (assimilated and unassimilated), calques (loan translations, loan renditions and semantic loans) and loan creations.

Thomas is also vague as to the exact types of replacement tolerated by the various levels of purism. Extreme purism, for example, targets both Lehnübersetzungen and Lehnübertragungen, but also apparently accepts some of the former as replacements, although Thomas does not give further details as to which are tolerated or why. ${ }^{4}$

3 This analysis is based upon Loï Depecker's account of terms targeted and replaced by the terminology commissions in France (200I: 402-425) and the document Politique de l'emprunt linguistique produced by the Office québécois de la langue française.

${ }^{4}$ Lehnübersetzungen relates to 'loan translation' and Lehnübertragungen to 'loan rendition' in our revised typology of borrowings. 


\section{Olivia Walsh}

Additionally, although his model does not allow for assimilated or unassimilated loanwords from non-related languages to be tolerated as replacements, both have been used as official replacements in France and Quebec. It has proved necessary, therefore, to expand Thomas's model. Mild purism is henceforth characterised by the acceptance of loanwords from unrelated languages, both assimilated and unassimilated, and moderate purism by loan translations and loan renditions that conform to native word-building laws, semantic loans and loan creations.

\section{THE QUESTIONNAIRE}

The survey was carried out using an anonymous questionnaire, which respondents completed and submitted online. Of various survey methods available, an online questionnaire was seen as the most appropriate because it allows data to be collected from a large number of subjects simultaneously, requiring far fewer financial or temporal resources than conducting interviews with a similar number of respondents; it enables data to be gathered in a very uniform and reliable manner, as each person responds to exactly the same question; and it allows anonymity, which increases the chances of collecting data that actually reflect respondents' true beliefs and attitudes. The social desirability bias, which refers to the tendency for respondents to respond to questions in a way that makes them appear more prestigious (Baker, I992: I8) is likely to be far less significant in an anonymous questionnaire than it may be in face-to-face interviews.

The questionnaire used a direct approach, gathering responses to direct questions about language, that is, the respondents were overtly asked to report their attitudes. When self-report procedures are used, it is assumed that the subjects whose attitudes are being assessed are able both to recognise their own beliefs and feelings and to articulate these properly, and also to have no reason to misrepresent their attitudes (Henerson, Morris and Fitz-Gibbon, I987: 20). This type of approach is usually used unless it is believed that the subjects whose attitudes are being assessed are either unable or unwilling to report their attitudes. This is not the case for the current study; there is no reason to believe that either French or Québécois respondents would be unable or unwilling to report their attitudes towards the French language, in particular when responding to an anonymous questionnaire such as this one.

The parts of the questionnaire under discussion used cloze-test type exercises and acceptability judgements to test the acceptability of anglicisms, terms recommended by the terminology commissions and frequently occurring usages which contravene prescriptive grammar. This allowed us to measure both the attitudes and the behaviour of respondents.

A link to the questionnaire was first forwarded to personal contacts, including contacts at several universities and contacts working in various companies in different areas of France and Quebec, who then passed it on to their colleagues and friends. As this did not provide a high number of responses, the questionnaire was then forwarded to schools, universities (academic departments, social groups, sports groups), trade unions and professional associations, and retiree associations 


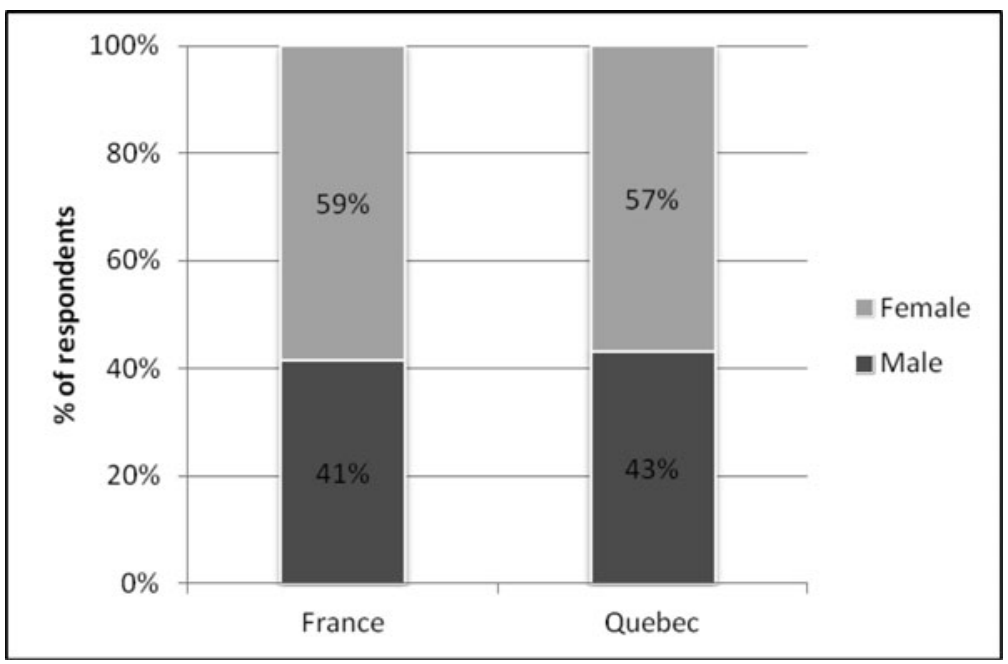

Figure 2. Sex of respondents

(professional associations, sports and activity groups) all over France and Quebec. In order to avoid sending the link as uninvited spam to large numbers of unknown recipients, in each case the moderator of the group (for social and sports clubs, for example) or the relevant administrator (such as the department secretary or school administrator) was contacted for permission to send on the link. ${ }^{5}$

\subsection{Social characteristics of questionnaire respondents}

The questionnaire received a total of I,608 responses. In order to be retained, respondents had to be monolingual French speakers, be of French or Québécois/Canadian nationality and be resident in France or Quebec. This left a total of I,I37 respondents, of whom 40I were French and 736 Québécois. The dataset is therefore somewhat asymmetrical; however, the large number of respondents should mitigate the effects of this asymmetry.

As shown in Figure 2, a slightly greater proportion of respondents were female in both France and Quebec.

The questionnaire included three age groups: a younger group, aged from is to 24; a middle group aged between 25 and 64; and an older group aged over 65 . These correspond roughly to Ager's three stages, which he claims are linguistically relevant: 'the period of schooling; the period of economic activity; and the period

5 The problems inherent in online, anonymous studies of this type, in particular the fact that participants are essentially self-selecting, may mean that the results do not reflect the attitudes of the French speech community as a whole. However, the large numbers of respondents may mitigate this. 


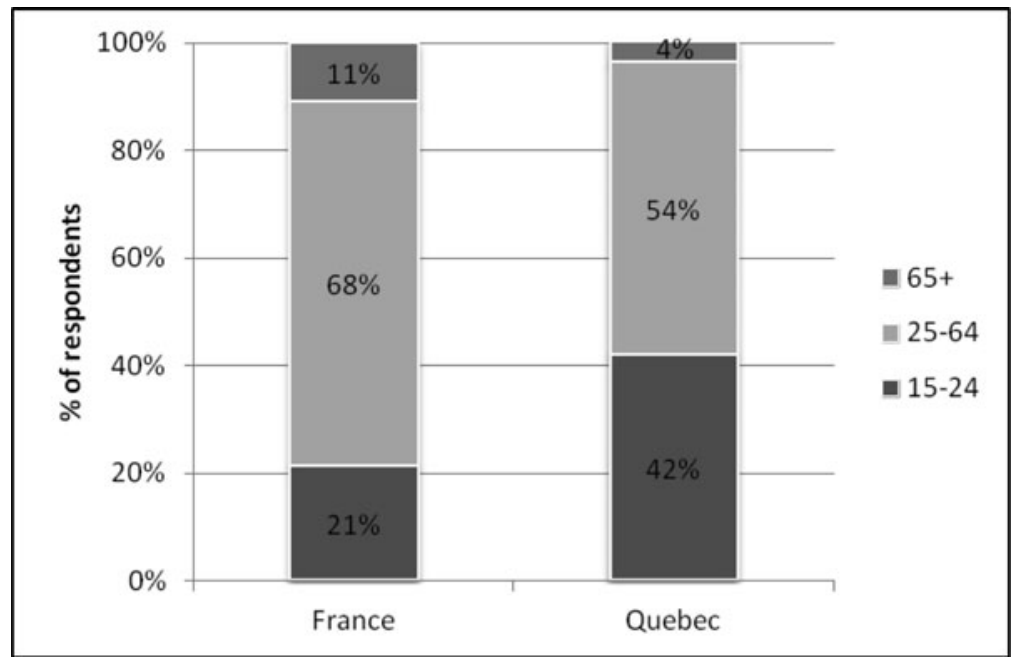

Figure 3. Age of respondents

up to retirement, roughly definable as three unequal groups of people aged up to I9, from 20 to 59, and those over 60' (Ager, I990: I I3). The groups do not match Ager's for various reasons, indeed Ager himself admits that there are no clear-cut divisions for these groups (ibid.). The younger age group includes speakers up to the age of 24 , based upon the reasoning firstly, that it is usual for the period of 'schooling' to last well into the early twenties and secondly, that although respondents under the age of 25 may well have begun to work in the professional arena, the pressures towards using more standard forms that may occur when speakers become firmly entrenched in the professional arena are unlikely to have taken strong hold. From the age of 25 onwards, one might expect career to become more important and market pressures towards standardisation may begin to operate. The older group is also slightly older at 65 , because although 60 is the normal age of retirement in France, it is 65 in Quebec.

As shown in Figure 3, by far the greatest number of respondents were aged between 25 and 64, which is to be expected, given that this group has the greatest age span. In Quebec, there were twice as many respondents in the younger group than in France, but the reverse was true for the older group, with nearly three times as many respondents in France. Although these may look like relatively small percentages, the high number of respondents means that the numbers involved are more than adequate for comparative and statistical purposes.

The questionnaire included three education groups: Level I, lower than schoolleaving certificate; Level 2, school-leaving certificate; Level 3, third-level education. As Figure 4 shows, the majority of both French and Québécois respondents have Level 3 education, although the proportion is slightly higher for French respondents, 


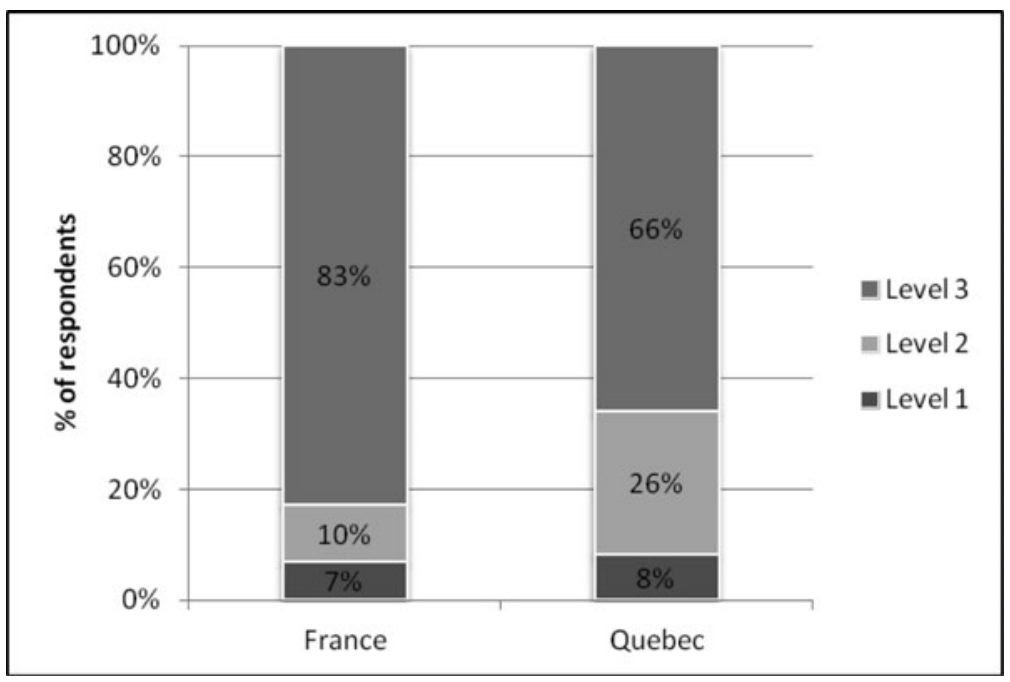

Figure 4. Level of education of respondents

and there is a correspondingly higher proportion of Québécois respondents with a school-leaving certificate.

Although the graphs displaying the results for each section are proportional representations and therefore the different tendencies of each group can be clearly displayed, the variation in numbers must naturally lead us towards caution in interpreting these graphs. However, the statistical tests applied using the statistical package SPSS take uneven distributions into account and correct for these, which allows us to clearly determine which results are significant.

\subsection{Questionnaire methodology}

The questionnaire was composed of six parts, of which two are discussed here, those relating directly to Thomas's model (parts IIa and IIb). ${ }^{6}$ Part IIa of the questionnaire was designed to investigate the level of external purism in France and Quebec in two ways: firstly, by investigating whether, given a choice, respondents would choose to use an unassimilated loanword or its French replacement and, if they chose the replacement, whether they would choose an assimilated loanword or a calque; and secondly, by investigating how likely respondents were to choose a terminology commission term. The sentences displayed in Figure 5 were shown on the screen, each with a gap and a choice of three terms to fill this gap: an

${ }^{6}$ Part I elicited information on social characteristics, and parts III, IV and V measured respondents' general attitudes to the English language, to the French language and to the use of anglicisms in French, respectively. 
Vous trouverez ci-dessous plusieurs phrases à trou. Pour chaque phrase, vous avez un choix de trois termes pour remplir la phrase. Veuillez choisir le terme que vous utiliseriez en parlant avec un ami.

1. Internet Explorer, Firefox et Google Chrome sont tous des

browsers

logiciels de navigation

navigateurs

2. On utilise le terme pour désigner un logiciel qui a pour fonction de faire respecter la politique de sécurité d'un réseau.

barrière de sécurité

firewall

pare feu

3. On utilise souvent le langage HTML pour créer une page sur la toile

page web

webpage

4. J'ai acheté un pour transformer mes vieilles photos en images numériques et les mettre sur CD-Rom.

scanner

numériseur

scanneur

5. Je serais perdu sans mon pour sauvegarder les données importantes comme les rendez-vous et les adresses.

organiseur

agenda électronique

organiser

6. Le __ est responsable de la gestion et de la maintenance du site web.

webmestre

administrateur de site

webmaster

Figure 5. Part IIa of the questionnaire 


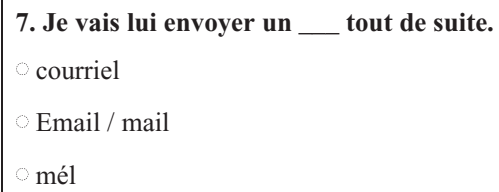
continuent à recevoir des bonus.

Figure 5. Continued ${ }^{7}$

unassimilated loanword; an assimilated loanword; or a calque (a loan rendition, semantic loan or loan creation).

According to Thomas's model, we would expect respondents displaying no discernible purism to choose mainly unassimilated loanwords, respondents displaying mild purism to choose mainly assimilated loanwords and respondents displaying moderate purism to choose mainly calques. ${ }^{8}$ For each sentence in

7 These terms were chosen because all are terms targeted by the terminology commissions in both France and Quebec, and are also terms that, while relating to the IT domain, have become relatively unspecialised, having passed into common usage (based upon analysis by native French and Québécois speakers of French during development of the questionnaire). Given their common usage, it was assumed that respondents would be at least somewhat familiar with such terminology.

${ }^{8}$ Whilst it is possible that the presence of two forms with similar orthographies in each sentence may have favoured the selection of one of these, both the high percentage of calques selected by Québécois respondents (see Figure 7 below) and the marked difference shown between French and Québécois respondents in this exercise would suggest that this is not the case here. 
Table 2. Terms used in part II

\begin{tabular}{|c|c|c|c|c|c|}
\hline \multirow[b]{2}{*}{ Sentence } & \multirow{2}{*}{$\begin{array}{l}\text { Group I } \\
\text { unassimilated } \\
\text { loanwords }\end{array}$} & \multirow{2}{*}{$\begin{array}{l}\text { Group } 2 \\
\text { assimilated } \\
\text { loanwords }\end{array}$} & \multicolumn{3}{|c|}{ Group 3 (calques) } \\
\hline & & & $\begin{array}{l}\text { loan } \\
\text { renditions }\end{array}$ & $\begin{array}{l}\text { semantic } \\
\text { loans }\end{array}$ & $\begin{array}{l}\text { loan } \\
\text { creations }\end{array}$ \\
\hline I & browsers & & navigateurs & & $\begin{array}{l}\text { logiciels de } \\
\text { navigation }\end{array}$ \\
\hline 2 & firewall & & pare feu & $\begin{array}{l}\text { barrière de } \\
\text { sécurité }\end{array}$ & \\
\hline 3 & webpage & page web & $\begin{array}{l}\text { page sur la } \\
\text { toile }\end{array}$ & & \\
\hline 4 & scanner & scanneur & & & numériseur \\
\hline 5 & organiser & organiseur & & & $\begin{array}{l}\text { agenda } \\
\text { électronique }\end{array}$ \\
\hline 6 & webmaster & webmestre & & & $\begin{array}{l}\text { administrateur } \\
\text { de site }\end{array}$ \\
\hline 7 & email & mél & & & courriel \\
\hline 8 & webcam & webcaméra & cybercaméra & & \\
\hline 9 & blog & blogue & & bloc-notes & \\
\hline IO & traders & tradeurs & & & $\begin{array}{l}\text { opérateurs de } \\
\text { marché }\end{array}$ \\
\hline
\end{tabular}

this section, one term out of the three was also a term recommended by the terminology commissions in France and Quebec. As terminology commission terms are generally created to replace an existing anglicism, we can assume that choosing one of these displays a stronger level of purism. This exercise also allows us to see whether there is any difference in the acceptance of terminology commission terms in France and Quebec. Note that respondents' actual behaviour may not necessarily mirror their stated behaviour here, but in order to try and account for this, they were asked to choose the term they would use when speaking to a friend, as it was felt that such a scenario may make them more likely to report the term they would use spontaneously. The terms included in part IIa are listed in Table 2. French terminology commission terms are highlighted in bold and Québécois terminology commission terms in italics. Where these coincide, they are highlighted in bold italics. ${ }^{9}$

Part IIb was designed to examine attitudes towards borrowed English terms, terminology commission terms and 'correctness', that is, to investigate levels of both external and internal (elitist) purism. The eleven sentences displayed in Figure 6 were presented on screen and respondents were asked to read each sentence and to state whether or not they found it satisfactory. If not, they were then asked to enter the part they found unacceptable into a text box and to state what they would use instead.

9 Sentences 3-IO are used to measure the types of terms favoured for replacing borrowed terms and sentences, sentences $\mathrm{I}-9$ are used to measure the likelihood of respondents choosing a terminology commission term. 
Vous trouverez ci-dessous plusieurs phrases. Pour chaque phrase, veuillez indiquer si vous y trouvez une expression que vous n'utilisez pas en français. $\mathrm{Si}$ c'est le cas, veuillez taper l'expression que vous n'utilisez pas dans le champ texte fourni et, si possible, mettre l'expression que vous utiliseriez à la place.

1. Le directeur a organisé un grand casting afin de trouver la vedette du nouveau film.

Cette phrase me satisfait.

Il y a une expression dans cette phrase que je n'utilise pas.

2. J'irai au ciné toute seule ce soir, à moins que tu viennes avec moi.

Cette phrase me satisfait.

Il y a une expression dans cette phrase que je n'utilise pas.

3. Les nouveaux réseaux sociaux en ligne comme Facebook et Twitter ont fait apparaître beaucoup de nouvelles façons de faire du marketing.

Cette phrase me satisfait.

Il y a une expression dans cette phrase que je n'utilise pas.

4. Après qu'il soit parti, j'ai mangé trois paquets de chips.

Cette phrase me satisfait.

Il y a une expression dans cette phrase que je n'utilise pas.

5. La pomme que j’ai mangé ce matin m'a donné mal au ventre.

Cette phrase me satisfait.

Il y a une expression dans cette phrase que je n'utilise pas.

6. Il y a beaucoup de sites suspects sur la toile, il faut donc faire attention à ne pas y mettre trop d'informations personnelles.

Figure 6. Part IIb of the questionnaire

Three of the I I sentences contained unassimilated loanwords (I. 'casting', 3. 'marketing', 8. 'hamburger'), three included a terminology commission term (6. 'toile', 7. 'réamorcer', Io. 'baladodiffusion') and five included usages that do not conform to prescriptive norms (sentences 2, 4, 5, 9 and I I, see below Table 3). The sentences were presented in random order. This exercise aimed to determine, firstly, whether or not speakers would highlight commonly used anglicisms as unacceptable, secondly, whether or not they would highlight terminology 
Cette phrase me satisfait.
Il y a une expression dans cette phrase que je n'utilise pas.

7. Si vous avez un problème avec votre ordinateur, le plus simple est de le réamorcer.

Cette phrase me satisfait.

Il y a une expression dans cette phrase que je n'utilise pas.

8. Il ne faut pas manger trop de hamburgers, ça fait grossir.

Cette phrase me satisfait.

Il y a une expression dans cette phrase que je n'utilise pas.

9. Monsieur le Président, qu'est-ce que vous allez faire pour les retraites?

Cette phrase me satisfait.

Il y a une expression dans cette phrase que je n'utilise pas.

10. La baladodiffusion est un nouvel outil qui permet d'écouter des émissions quand on veut et pas seulement à heure fixe.

Cette phrase me satisfait.

Il y a une expression dans cette phrase que je n'utilise pas.

11. Cette fille je l'ai entendu jouer du violon l'année dernière et elle est très douée.

Cette phrase me satisfait.

Il y a une expression dans cette phrase que je n'utilise pas.

Figure 6. Continued

commission replacements as unacceptable and thirdly, whether or not they would notice, and condemn, usages which are contrary to the prescribed norms of French. The first aimed to measure attitudes to the targets of purism, the second to measure attitudes to replacements and the third to measure levels of elitist purism.

\subsection{Questionnaire results}

The results of the questionnaire were analysed quantitatively, combining descriptive statistics with tests for statistical significance, where these were deemed appropriate. 
The descriptive statistics mainly provide overall frequencies and percentages, and the test for statistical significance used is a contingency chi-square test, which gives a measure of the likelihood of the results observed being due to chance, or due to the effect of the independent variables investigated. This was used to test the effect of nationality (French or Québécois) and also to test the effect of the independent variables sex, age and level of education on the data. As is standard in the social sciences, a $\mathrm{p}$ value of less than 0.05 is regarded as significant.

In order to ensure that the data were representative of the larger populations in France and Quebec, they were analysed according to the social categories of sex, age and education. Although, as we have seen, the dataset displayed slightly uneven distributions for these factors, upon analysis, these differences caused few significant results and any results suggesting a possible influence were highly inconclusive. There were no significant results for sex. While age appeared to have a slight influence on responses to part IIa, with older respondents marginally more likely to display a purist attitude, this result was not repeated in part IIb, where no clear pattern emerged to suggest a meaningful relationship between age and the responses to this section. In France, the responses to part IIa also appeared to show a correlation between purism and level of education, with more highly educated respondents more likely to display a less purist view than respondents with fewer qualifications. In Quebec, however, the situation was unclear. Again, the results were not repeated in part IIb. Given that none of the results suggesting any possible influence of these social factors were conclusive enough to draw any wider inferences, they are excluded from the rest of this discussion. For more detailed information on these social factors, see Walsh (20I3).

The results for Part IIa of the questionnaire show quite a marked difference in the types of terms chosen by French and Québécois respondents. Figure 7 shows that French respondents were far more likely to choose unassimilated loans and far less likely to choose either assimilated loans or calques, ${ }^{10}$ which would suggest that they display a milder level of purism. A chi-square test confirms that this difference is highly statistically significant $(\mathrm{p} \leq \mathrm{O} . \mathrm{OOI})$.

When we look at the type of 'calques' chosen in more detail, there is also a difference between France and Quebec. As shown in Figure 8, where there was a choice between an unassimilated loan, an assimilated loan and a loan rendition, more Québécois respondents chose a loan rendition. A chi-square test shows that this is a statistically significant result $(\mathrm{p} \leq \mathrm{O} . \mathrm{OOI})$.

Similarly, where there was a choice between an unassimilated loan, an assimilated loan and a loan creation, markedly more Québécois respondents chose the loan

10 Table 2 shows that the terms recommended by the Québécois terminology commission are more likely to be calques than those recommended by the French terminology commissions, which may have an influence on the results here. This is a factor which it would be interesting to explore more fully in a subsequent study. However, French respondents remain more likely to choose the non-recommended unassimilated loanwords than their Québécois counterparts. 


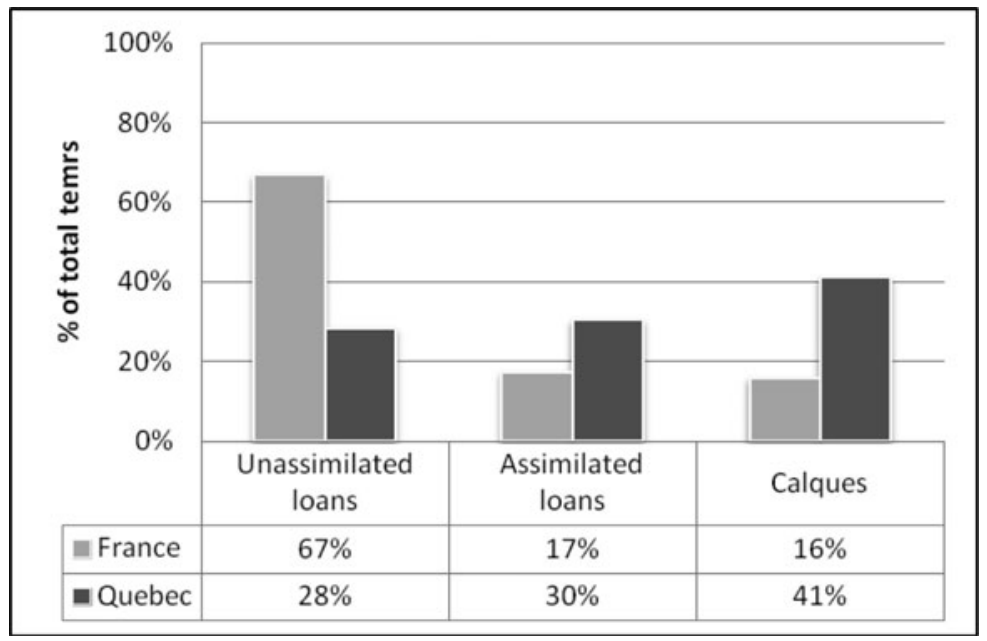

Figure 7. Type of term chosen

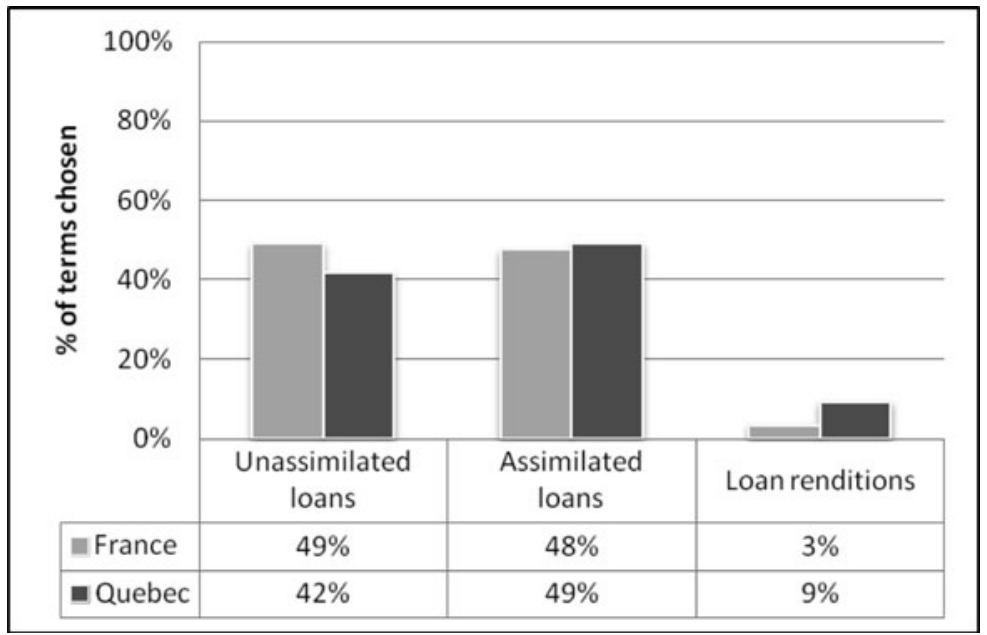

Figure 8. Loan renditions chosen

creation, as we can see in Figure 9. A chi-square test confirms that this is also a significant result $(\mathrm{p} \leq \mathrm{0.00 \textrm {I }})$.

These results indicate that Québécois respondents once again display a higher level of purism than French respondents, as loan renditions and loan creations correspond to a moderate level of purism in Thomas's model.

Québécois respondents were also far more likely to choose a terminology commission term, as is clearly displayed in Figure Io. A chi-square test confirms 
'Les anglicismes polluent la langue française'

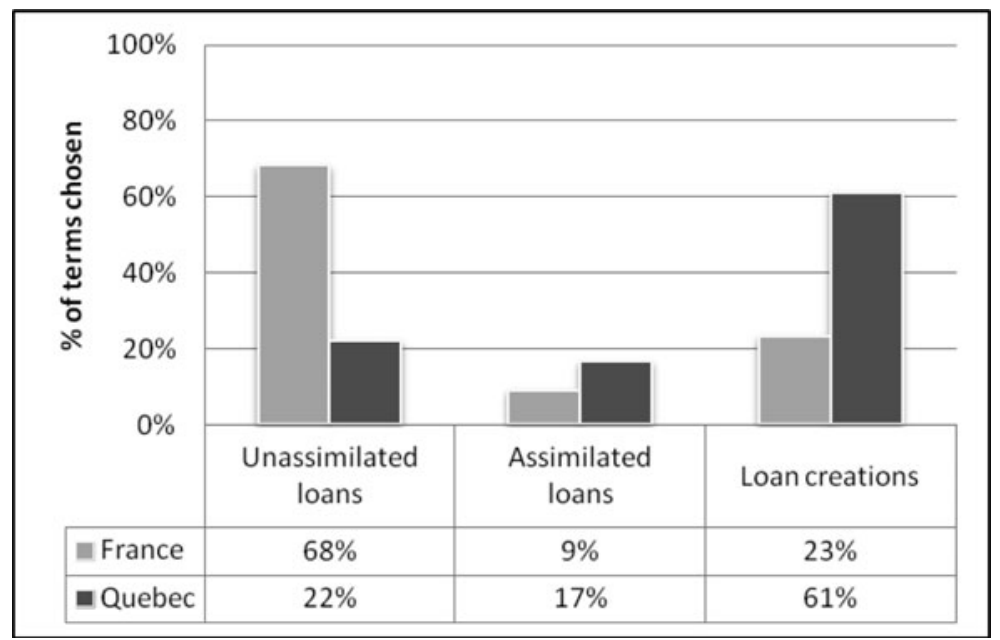

Figure 9. Loan creations chosen

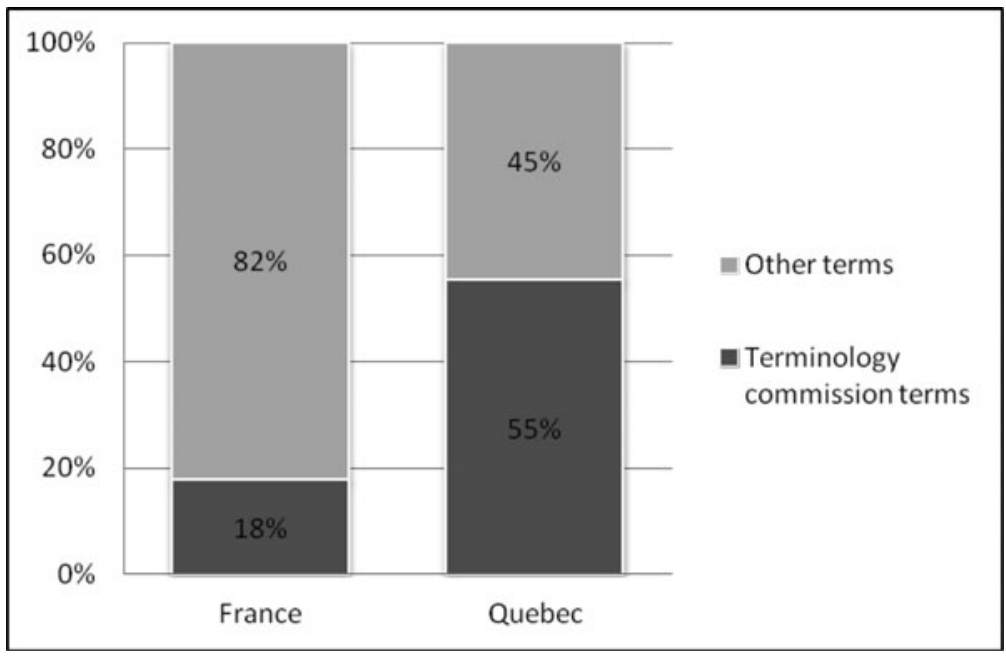

Figure Io. Terminology commission terms chosen

that this result is highly significant $(\mathrm{p} \leq \mathrm{O} . \mathrm{OOI})$, which may suggest that terminology commission terms are more successfully implanted in Quebec than in France.

To summarise, in part IIa, Québécois respondents were significantly more likely to display a more strongly purist attitude than their French counterparts. They were also more likely to choose terminology commission terms, which may suggest that 


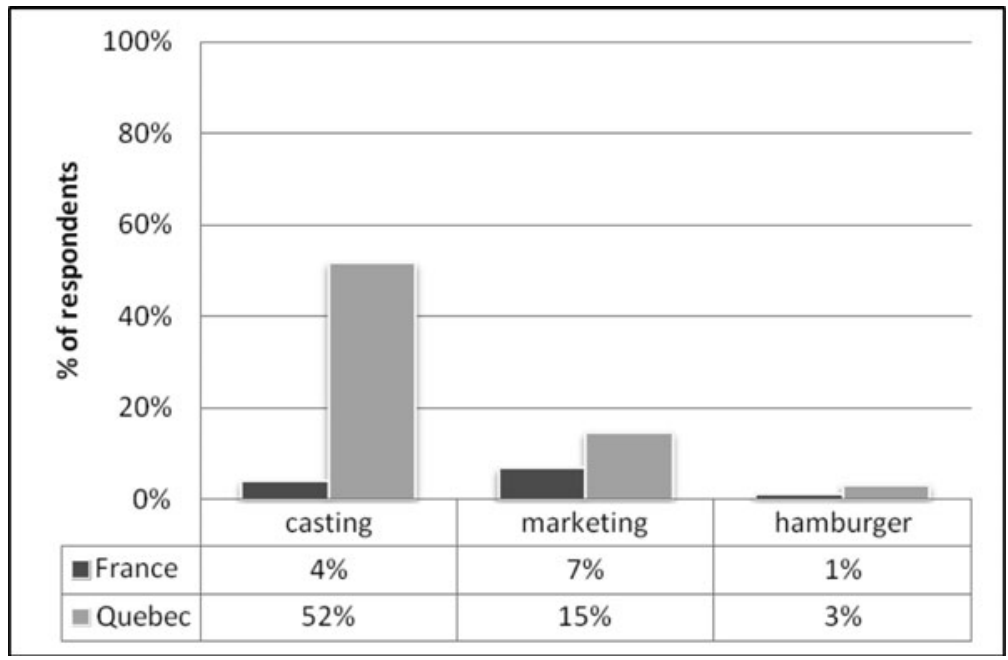

Figure I I. Percentage of respondents finding anglicisms unacceptable

the promotion and implantation of such terms is more widespread in Quebec than in France.

The results for part IIb appear to reinforce these findings. The three anglicisms used here were 'casting', 'marketing' and 'hamburger'. As Figure II shows, Québécois respondents showed a more marked aversion to the anglicisms than their French counterparts, very few of whom noted or commented on them. A marginal difference was displayed even for the exceptionally common and widespread term 'hamburger', with 3\% of Québécois respondents finding this unacceptable compared to $\mathrm{I} \%$ of French respondents. A chi-square test shows this result to be significant for the sentences containing 'casting' and 'marketing' ( $\mathrm{p} \leq \mathrm{O} . \mathrm{OO}$ I for both), which may indicate that Québécois respondents find anglicisms less acceptable than French respondents.

The three terminology commission terms included in part IIb, toile ('web'), réamorcer ('reboot') and baladodiffusion ('podcast'), do not have equal status in France and Quebec. In France, the official recommendation for 'podcast' is diffusion pour baladeur, with baladodiffusion given as a synonym used in Quebec. In Quebec, the official recommendation for 'reboot' is redémarrer and for 'web' is web, with réamorcer and toile given as the synonyms used in France. Thus, if we assume that terms recommended by the terminology commissions become accepted into general usage, we may expect more Québécois respondents to accept baladodiffusion and more French respondents to accept réamorcer and toile. This is indeed the case, but while there is a very clear difference for baladodiffusion, which a markedly higher proportion of Québécois respondents find acceptable, only slightly 


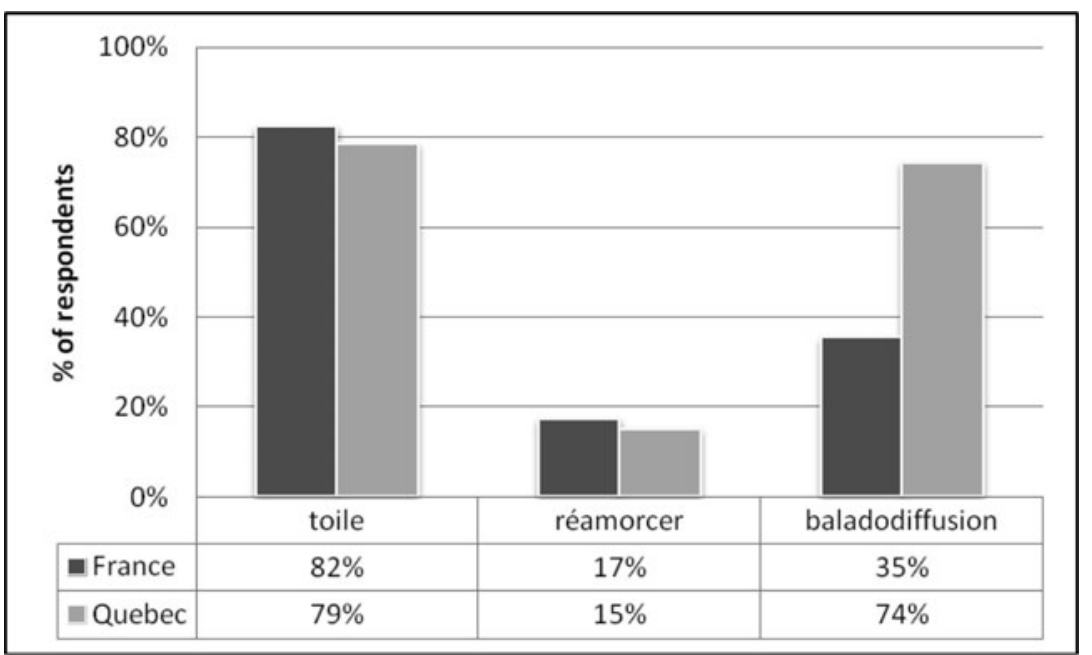

Figure I2. Percentage of respondents finding terminology commission terms acceptable

more respondents in France find réamorcer or toile acceptable, as we can see in Figure I $2 .{ }^{11}$

It is unclear why so many respondents find toile acceptable enough to pass no comment on it, when so many find réamorcer unacceptable. The terms were created in 1999 and 1998 , respectively, so the length of time they have existed as recommended terms is unlikely to play a role. One explanatory factor may be that we are dealing with a noun rather than a verb, and we know that nouns are borrowed more easily than verbs, possibly due to the fact that they are more easily integrated into the language (cf. Poplack, Sankoff and Miller, I988). What is interesting is that while more or less the same proportion of French and Québécois respondents find toile and réamorcer acceptable (although these are French terminology commission recommendations, and we might therefore expect a higher proportion of French respondents to find them acceptable), a far higher proportion of Québécois respondents find baladodiffusion acceptable. We could perhaps see this as an indication that terminology commission terms are more likely to become well-known or accepted in Quebec than in France, which may also be related to the manner in which they are promoted. This result would appear to reinforce the results from part IIa, although it must naturally be interpreted with caution, given that we are only dealing with a very small number of individual terms here.

Of the respondents who found the use of the term réamorcer unacceptable, many suggested a replacement term. Figure I 3 shows that while $89 \%$ of the

11 Note that we are working on the assumption that respondents find the term acceptable if they find the sentence acceptable and do not comment on the term. 


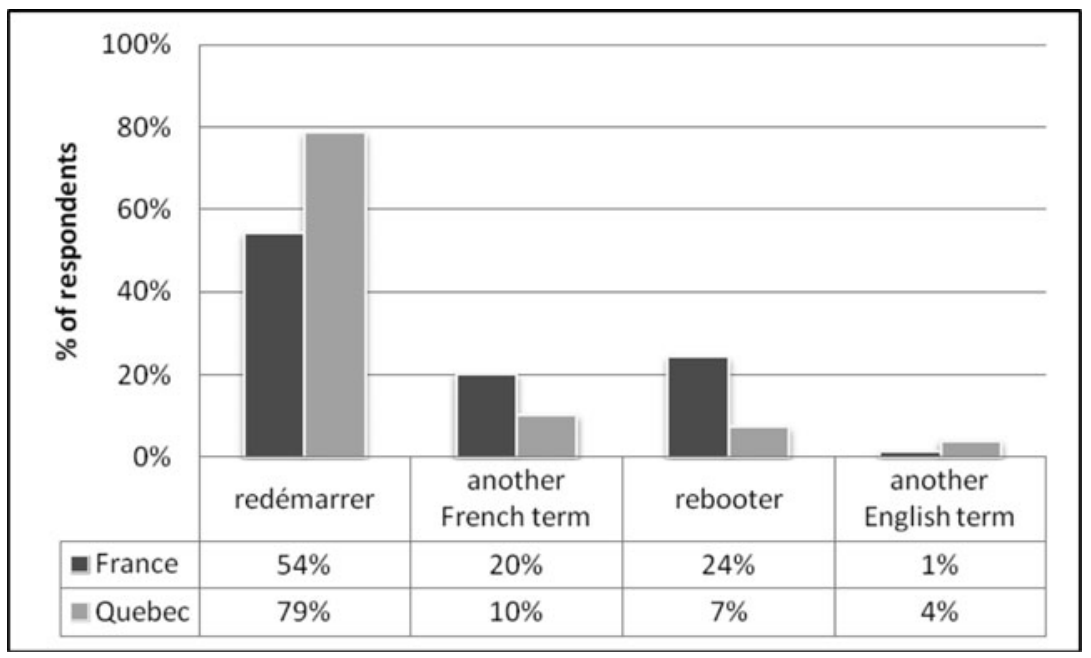

Figure I3. Alternative terms suggested for 'réamorcer'

replacement terms suggested by Québécois respondents were French terms (e.g. redémarrer, relancer), and II\% assimilated loanwords from English (e.g. rebooter/rebouter, restarter), $74 \%$ of the replacement terms suggested by French respondents were French terms and 26\% were English loanwords, suggesting that French respondents are slightly more open towards using anglicisms. Furthermore, a higher proportion of Québécois respondents suggested redémarrer, the official Québécois recommendation, as a replacement term for réamorcer.

As demonstrated in Figure I2, more Québécois respondents found the term balladodiffusion acceptable than French respondents. Figure I4 shows that, of the respondents who found the term unacceptable and gave a reason for this, $40 \%$ of French respondents stated that they would use the original anglicism podcast instead, compared to only I $8 \%$ of Québécois respondents. This again reinforces earlier results suggesting that Québécois respondents are more reluctant to use anglicisms.

The remaining five sentences in part IIb each contain a commonly occurring usage which would be considered contrary to prescribed usage in normative grammar. These sentences were included to see whether respondents would notice the 'errors' and comment upon them, thereby displaying elitist purism. The sentences are displayed in Table 3. These usages were chosen upon the advice of a French native speaker and French language teacher, who indicated that all were very common. As all are also noted as being contrary to prescribed usage in Riegel, Pellat and Rioul (2004), which is widely used in both France and Quebec, we can assume that they correspond to the standard in both places. The distinction between written and spoken language, which may play a role in acceptability judgements, was not referred to in the questionnaire; however, there was scope for respondents 


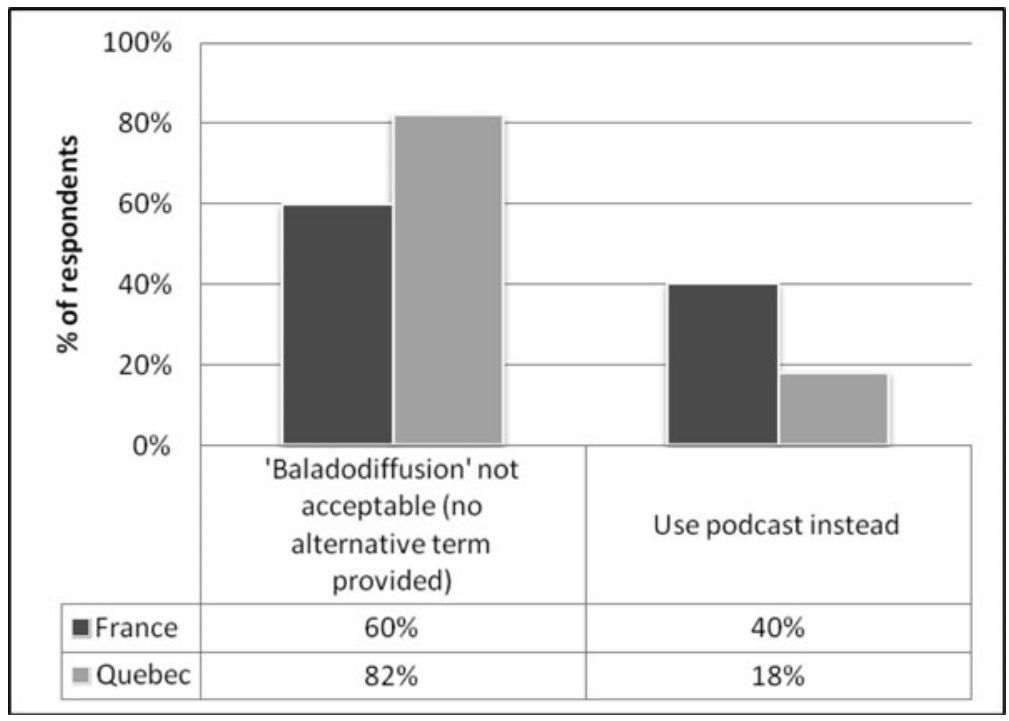

Figure I 4. Alternative terms suggested for 'baladodiffusion'

Table 3. Usages contrary to prescribed norms included in Part IIb

\begin{tabular}{|c|c|}
\hline Sentence included in questionnaire & Normative version \\
\hline $\begin{array}{l}\text { J'irai au ciné toute seule ce soir, à moins } \\
\text { que tu viennes avec moi. }\end{array}$ & $\begin{array}{l}\text { J'irai au ciné toute seule ce soir, à moins } \\
\text { que tu ne viennes avec moi. }\end{array}$ \\
\hline $\begin{array}{l}\text { Après qu'il soit parti, j'ai mangé trois } \\
\text { paquets de chips. }\end{array}$ & $\begin{array}{l}\text { Après qu'il est parti, j’ai mangé trois } \\
\text { paquets de chips. }{ }^{12}\end{array}$ \\
\hline $\begin{array}{l}\text { La pomme que j'ai mangé ce matin } \\
\text { m'a donné mal au ventre. }\end{array}$ & $\begin{array}{l}\text { La pomme que j’ai mangée ce matin m'a } \\
\text { donné mal au ventre. }\end{array}$ \\
\hline $\begin{array}{l}\text { Monsieur le Président, qu'est-ce que } \\
\text { vous allez faire pour les retraités }{ }^{13}\end{array}$ & $\begin{array}{l}\text { Monsieur le Président, qu'allez-vous faire } \\
\text { pour les retraités? }\end{array}$ \\
\hline $\begin{array}{l}\text { Cette fille je l'ai entendu jouer du } \\
\text { violon l'année dernière et elle est très } \\
\text { douée. }\end{array}$ & $\begin{array}{l}\text { Cette fille je l'ai entendue jouer du violon } \\
\text { l'année dernière et elle est très douée. }\end{array}$ \\
\hline
\end{tabular}

to mention this in the comments box beneath each sentence if it occurred to them spontaneously. In fact, extremely few respondents commented on this, the few who

I2 Note that Riegal, Pellat and Rioul state that 'après que' has begun to be followed by the indicatif by analogy with 'avant que', although they still state that this is a non-normative usage: 'On est contraint de constater que le subjonctif se répand dans les subordonnées introduites par après que, contre la logique et la correction des puristes : Il repassera nous voir après que nous ayons dîné. On peut invoquer pour expliquer cette anomalie, bizarrement limitée au seul après que, l'analogie avec avant que' (2004: 507). Given that this usage is becoming more common, it may indicate a higher level of purism amongst respondents who notice it and comment that it is an error.

I3 Note that the context in this sentence is intended to portray a formal situation and, therefore, a normative preference for question inversion. 


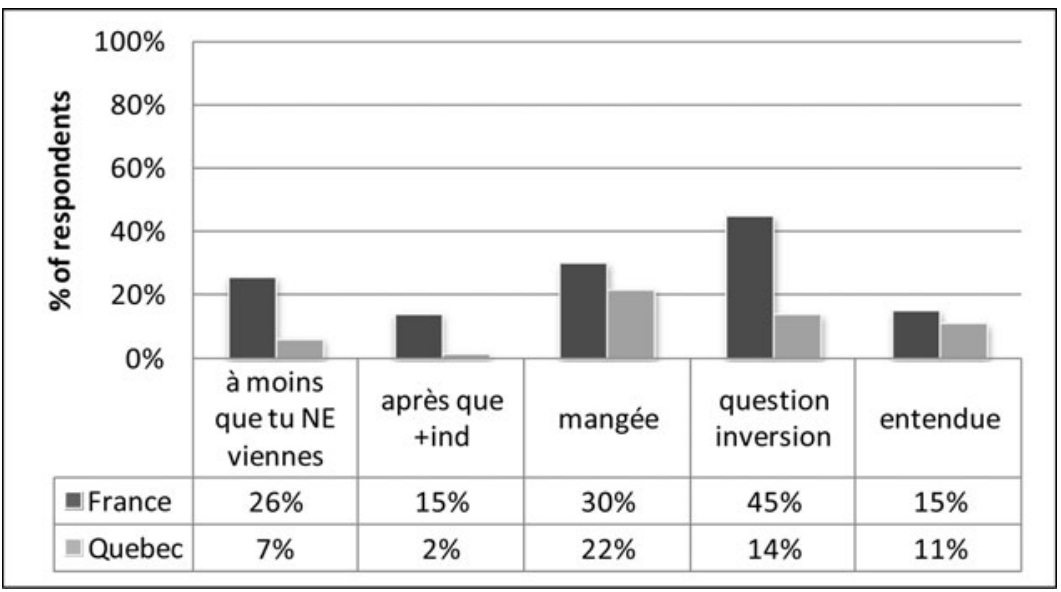

Figure I 5. Proportion of respondents who found the 'error' unacceptable

did indicating that a particular usage may occur more frequently in spoken French, although this did not affect them from finding it unacceptable.

Figure I 5 shows that there is a fairly marked difference between France and Quebec in the proportion of respondents who noted these usages and stated that they found the sentence unacceptable. Chi-square tests run on each of these results individually confirm that all are highly significant $(\mathrm{p} \leq 0.00 \mathrm{I})$, and that there is therefore a correlation between nationality and reactions to these usages.

In each case, far more French respondents commented on the 'error' than Québécois respondents. It must, however, be noted that the sentences 'J'irai au ciné toute seule ce soir, à moins que tu viennes avec moi' and 'Après qu'il soit parti, j'ai mangé trois paquets de chips' contained French terms that are little used by Québécois speakers, which may have skewed the results slightly. The former sentence contains the shortened term 'ciné' which is rarely used in Quebec and many respondents stated that they found the sentence unacceptable due to the use of this term. Similarly, the term 'paquet de chips' is not common in Quebec, the alternative 'sac de croustilles' being used. Naturally, only those responses which clearly show that the sentence was unacceptable due to the usage we were measuring are included in the results in Figure I 5 , and the fact that the difference is so marked and that there is also a significant difference displayed in the other three sentences implies that French respondents display more awareness of deviations from the norm. This suggests that internal purism of the elitist kind is stronger in France than in Quebec.

The results of part IIb suggest that Québécois respondents are more likely than their French counterparts to display external purism, whereas the latter are more likely to display internal purism, specifically, elitist purism. 
Although Thomas's framework displays some weaknesses - the terminology used to describe the targets and replacements of purism is vague and no clear definitions or examples are provided, and the model, although supposedly applicable crosslinguistically, does not allow for an accurate representation of the types of targets and replacements used by the French and Québécois terminology commissions once modifications were made to address these issues, the framework allowed us to provide a clear indication of the difference in the type and scale of purism between France and Quebec.

Firstly, the results indicate that external purism is evident in both France and Quebec, but displayed more strongly in Quebec. Internal purism, on the other hand, appears to be more clearly evident in France; only a small minority of Québécois respondents found the usages in part IIb that do not conform to prescriptive norms unacceptable. In terms of Thomas's framework of puristic intensity, with regard to the orientation of the purism, French speakers display moderate purism, combining both internal and external purism (xenophobic/elitist). Québécois speakers, on the other hand, can really only be said to display external purism, which indicates a mild level of purism.

In part IIa of the questionnaire, we evaluated respondents' ability to recognise terminology commission terms and their (self-reported) use of these. This exercise provided us with an indication of the success of implantation of such terms, which relates to the replacement stage of Thomas's purification cycle. $55 \%$ of terms chosen by Québécois respondents in this exercise were terminology commission terms, compared to only i $8 \%$ of those chosen by French respondents. This suggests that the replacement stage has been more successful in Quebec than in France, at least as far as these particular terms are concerned. Although we cannot say anything about the other stages of the purification cycle and cannot fully apply Thomas's framework for this category, the result nonetheless indicates that Quebec is moderately purist, according to the framework, whereas France is mildly purist.

In terms of the targets of linguistic purism, French respondents display mild purism: unassimilated loans were the most common choice in part IIa $(67 \%$ of all terms chosen), indicating that these are not viewed as targets, and French respondents were also very unlikely to comment on any of the unassimilated loanwords used in part IIb, which reinforces their acceptance of these. In Quebec, on the other hand, $4 \mathrm{I} \%$ of terms chosen in part IIa were calques and $30 \%$ were assimilated loanwords; the majority of respondents therefore appear to object to using unassimilated loanwords, and over two-fifths also object to using assimilated loanwords. Similarly, they were more likely to object to the unassimilated loanwords in part IIb. These results indicate that they display moderate purism.

In terms of the replacements of purism, the data again suggest that French respondents display mild purism: only $17 \%$ of terms chosen in part IIa were calques, the majority were unassimilated or assimilated loanwords, and in part IIb, French respondents were unlikely to find terminology commission replacement 
terms acceptable, instead preferring to use a borrowed English term. Québécois respondents, however, were far more likely to choose calques and therefore display moderate purism.

\section{CONCLUSIONS}

These results indicate that there is a higher level of external purism amongst Québécois respondents. Given the large sample size and the significance of the data, we can say with some confidence that Quebec displays a more strongly external puristic orientation than France. This casts doubt over both of the assumptions made at the outset, that France is highly purist and that it is more purist than Quebec, at least at the level of external purism. However, the results also suggest a higher level of internal purism amongst French respondents. This naturally poses the question, for what reason do such differences exist? A synchronic study does not allow us to account for the motivations behind, and reasons for, the current attitudes towards language in France and Quebec as outlined in this article, and a diachronic study of how such attitudes developed in the past is clearly now necessary to permit us to provide such an account. According to Thomas, purism only ever arises in situations where a standard language is in the process of being, or has already been, established (Thomas, I99I: I5). Quebec's distance from France and the comparative isolation of Quebec after British colonisation caused the language to develop differently from the French in France and the question of whether the standard should be a Canadian standard, the standard of France or some international version has also historically been, and remains, an issue. It may be that these factors have played a role in the development of different attitudes in France and Quebec. A diachronic study of these differences will allow us to examine the interaction between standardization and purism in both places and will also enable us to assess how broader political, cultural and economic developments in France and Quebec affected attitudes towards language and which factors were most likely to lead to the different types of linguistic purism we see today.

Address for correspondence:

Clare College

Trinity Lane

Cambridge

CB2 1 TL

$U K$

e-mail:omw23@cam.ac.uk

\section{REFERENCES}

Ager, D. E. (1990). Sociolinguistics and Contemporary French. Cambridge: Cambridge University Press.

Baker, C. (1992). Attitudes and Language. Clevedon: Multilingual Matters. 
Betz, W. (1944). Die Lehnbildungen und der abendländischen Sprachenausgleich. Beiträge zur Geschichte der deutschen Sprache und Literatur, 67: 275-302.

Depecker, L. (200I). L'invention de la langue: le choix de mots nouveaux. Armand ColinLarousse: Paris.

Haugen, E. (I950). The analysis of linguistic borrowing. Language, 26: 210-23 I.

Henerson, M., Morris, L. and Fitz-Gibbon, C. (1987). How to Measure Attitudes. Beverly Hills; London: Sage.

Humbley, J. (1974). Vers une typologie de l'emprunt linguistique. Cahiers de lexicologie, $25: 46-70$.

Office québécois de la langue française (2007). Politique de l'emprunt linguistique, $22 \mathrm{p}$.

Paveau, M.-A. and Rosier, L. (2008). La langue française: passions et polémiques. Paris: Vuibert.

Picone, M. D. (1996). Anglicisms, Neologisms and Dynamic French. Amsterdam: Benjamins.

Poplack, S., Sankoff, D. and Miller, C. (1988). The social correlates and linguistic processes of lexical borrowing and assimilation. Linguistics, 26.I: 47-IO4.

Riegel, M., Pellat, J.-C. and Rioul, R. (I994). Grammaire Méthodique du français. Paris: Presses Universitaires de France.

Thomas, G. (I99I). Linguistic Purism. London: Longman.

Walsh, O. (20I3). Linguistic purism in France and Quebec. PhD thesis, University of Cambridge.

Walter, H. (1997). L'Aventure des mots français venus d'ailleurs. Paris: R. Laffont.

Weinreich, U. (I953). Languages in Contact: Findings and Problems. New York: Linguistic Circle of New York. 